Volume 56

January 2012

\title{
The Obama Administration and the Prospects for a Democratic Presidency in a Post-9/11 World
}

Peter M. Shane

The Ohio State University Moritz College of Law

Follow this and additional works at: https://digitalcommons.nyls.edu/nyls_law_review

Part of the Law and Politics Commons, Law and Society Commons, Military, War, and Peace Commons, and the National Security Law Commons

\section{Recommended Citation}

Peter M. Shane, The Obama Administration and the Prospects for a Democratic Presidency in a Post-9/11 World, 56 N.Y.L. ScH. L. REV. 28 (2011-2012).

This Article is brought to you for free and open access by DigitalCommons@NYLS. It has been accepted for inclusion in NYLS Law Review by an authorized editor of DigitalCommons@NYLS. 
PETER M. SHANE

The Obama Administration and the Prospects for a Democratic Presidency in a Post-9/11 World

ABOUT THE AUTHOR: Jacob E. Davis and Jacob E. Davis II Chair in Law, The Ohio State University Moritz College of Law. 
THE PROSPECTS FOR A DEMOCRATIC PRESIDENCY IN A POST-9/11 WORLD

[W] hen I won [the] election in 2008, one of the reasons I think that people were excited about the campaign was the prospect that we would change how business is done in Washington. And we were in such a hurry to get things done that we didn't change how things got done. And I think that frustrated people.

- President Barack Obama ${ }^{1}$

We're taking a pragmatic approach to find the best solution to national security threats consistent with protection of civil liberties and the rule of law. And we're trying to avoid too many abstract front-end rules that limit our options here.

$$
\begin{array}{r}
\text { - David Kris, Assistant Attorney General for National } \\
\text { Security, U.S. Department of Justice }{ }^{2}
\end{array}
$$

\section{INTRODUCTION}

Beyond its horrific immediate consequences, the monstrous attacks of September 11 left behind a poisonous political legacy in the United States. Not the least of the harms inflicted was an intensification in the Bush administration's already zealous allegiance to presidentialism, a theory of government "that treat[s] our Constitution as vesting in the President a fixed and expansive category of executive authority largely immune to legislative control or judicial review." 3 Presidentialism operated in the Bush administration as more than an abstract philosophy. It functioned as a powerful guiding ethos in the behavior of executive branch officials. In both domestic and foreign policy-but, most fatefully, I would argue, with regard to military and national security policy-members of the Bush administration acted, to borrow Jack Goldsmith's phrase, as "executive power ideologues." In their hands, as I have written elsewhere, presidentialism bred "an insularity, defensiveness, and even arrogance within the executive branch that undermine[d] sound decisionmaking, discount[ed] the rule of law, and attenuate[d] the role of authentic deliberation in shaping political outcomes." ${ }^{5}$

The aggressive presidentialism of the Bush-Cheney regime undoubtedly affected how many supporters of presidential candidate Barack Obama understood his 2008 campaign slogan, "Change You Can Believe In.” The change they expected, or at

1. President Barack Obama, Press Conference by the President (Nov. 3, 2010), available at http://www. whitehouse.gov/the-press-office/2010/11/03/press-conference-president.

2. Interview by Am. Constitution Soc'y Blog with David S. Kris, Assistant U.S. Att'y Gen. for Nat'l Sec., in D.C. (Oct. 16, 2009), available at http://www.acslaw.org/node/14425.

3. Peter M. Shane, Madison's Nightmare: How Executive Power Threatens American Democracy 3 (2009).

4. Jack Goldsmith, The Terror Presidency: Law and Judgment Inside the Bush Administration 89 (2007).

5. Shane, supra note 3 , at 25 . 
least hoped for, was a full-throated repudiation of presidentialism as an ideology. In 2007 then senator Obama had called for "[n]o more ignoring the law when it is inconvenient." Many voters no doubt hoped for the replacement of presidentialism by an equally robust ideology of governance rooted in ideas like checks and balances, public accountability, and the rule of law.

In May 2009 President Obama seemed to be repaying that hope. In a major address at the National Archives on national security, he outlined a wide variety of measures his administration had taken or was initiating to protect the nation against terrorism. He prefaced his review, however, with the following:

I believe with every fiber of my being that in the long run we . . cannot keep this country safe unless we enlist the power of our most fundamental values. The documents that we hold in this very hall-the Declaration of Independence, the Constitution, the Bill of Rights-these are not simply words written into aging parchment. They are the foundation of liberty and justice in this country, and a light that shines for all who seek freedom, fairness, equality, and dignity around the world.

I stand here today as someone whose own life was made possible by these documents. My father came to these shores in search of the promise that they offered. My mother made me rise before dawn to learn their truths when I lived as a child in a foreign land. My own American journey was paved by generations of citizens who gave meaning to those simple words- "to form a more perfect union." I've studied the Constitution as a student, I've taught it as a teacher, I've been bound by it as a lawyer and a legislator. I took an oath to preserve, protect, and defend the Constitution as Commander-in-Chief, and as a citizen, I know that we must never, ever, turn our back on its enduring principles for expedience sake. ${ }^{7}$

Roughly halfway into his first term, however, President Obama-although acknowledging and, in significant ways, advancing those values-does not seem to have fully articulated a vision of the presidency that unambiguously turns its back on Bush-Cheney presidentialism. Despite genuine achievements, for example, in helping to depoliticize the Justice Department and advancing the cause of government openness, the "big ideas" guiding his conception of the presidency still seem obscure, even to many supporters. Instead of challenging the operating ideology of the Bush administration head-on, he has often appeared to offer mainly his pragmatism as his chief antidote to Bush-era abuses. By pragmatism, I mean the self-conscious preference for "practical" approaches to addressing problems and challenges, in which strategies are pursued based on facts, evidence, and structured rational discourse, but which are also largely accepting of what decisionmakers regard as existing material and political constraints on action. The epigram on national security policy that

6. Senator Barack Obama, Remarks at the Woodrow Wilson Center: The War We Need to Win (Aug. 1, 2007), http://www.wilsoncenter.org/events/docs/obamasp0807.pdf.

7. President Barack Obama, Remarks by the President on Nat'l Sec. (May 21, 2009) [hereinafter Obama Nat'1 Sec. Remarks], available at http://www.whitehouse.gov/the-press-office/remarks-presidentnational-security-5-21-09. 
heads this essay, from then assistant attorney general David Kris, seems to capture this mood.

To be sure, as compared to the Bush style of governance, an avowed turn to pragmatism may appear to be no small matter. On a host of issues, including many that are critically related to U.S. national security in a post-9/11 world, the Bush administration often seemed driven by ideology über alles. Conspicuous examples include the decision to invade Iraq, the actual manner in which the invasion was staged, and the defense of what everyone in the world except the Bush administration was ready to call "torture." These issues and many others looked to be all but predetermined by political pre-commitments in a way that seemed oblivious to the foreseeable consequences on the ground. Compared to, say, invading Iraq with seeming disregard for the inevitably resulting empowerment of Iran, there is much to be said for a policymaking approach that actually cares about outcomes.

A pragmatic approach to policymaking, however, can be coherently interpreted only within a substantive set of guiding values. Pursuing "practical strategies" energetically, while articulating substantive values only vaguely and occasionally, cannot succeed as an enduring antidote to Bush-style presidentialism. It cannot have the permeating impact on executive branch behavior that one might seek from a comprehensive re-articulation of the presidency based on checks and balances, public accountability, and the rule of law. This is so for two related reasons: First, without a substantive re-articulation of the presidency, many of the Obama administration's practical responses to particular problems are susceptible to being understood in presidentialist terms - and thus, as legitimating presidentialism of even the BushCheney sort. That is precisely why, despite very genuine differences between the Obama and Bush presidencies, President Obama's national security actions are frequently derided (or applauded) as being straightforward continuations of the prior administration. ${ }^{8}$ Second, unless presidential pragmatism is explicitly, even emphatically, linked to a set of larger beliefs about the role and nature of the presidency, it is unlikely to be an effective program for re-orienting executive branch behavior and mobilizing popular support. The actions of both government bureaucrats and voters in general are shaped by notions of who they are and the values to which they owe allegiance. "Sensible, balanced outcomes" is too thin and indeterminate a rallying cry to shape the identity of either citizens or officials in a way likely to redirect our political life. This is especially so when the dominant presidentialist narrative is so deeply entrenched in other cultural norms.

What I am suggesting here, of course, is not an abandonment of practicality, or a return to rigidly ideological decisionmaking guided by a different ideology. I mean instead to underscore the importance for presidential leadership of establishing clearly the substantive values that guide the Obama administration's pragmatism. When the administration makes controversial decisions, those decisions ought to be defensibleand publicly defended-within the terms of those larger values. Any hesitancy,

8. See Glenn Greenwald, Obama's embrace of Bush terrorism policies is celebrated as "Centrism," SAlon (May, 19, 2009), http://www.salon.com/news/opinion/glenn_greenwald/2009/05/19/obama. 
unwillingness, or inability to tie the administration's controversial decisions to its larger beliefs cannot help but cripple the attempt to position the Obama presidency as an effective alternative to the "executive power ideologues" it has succeeded.

To clarify this argument, Parts II and III of this essay examine the Obama administration's record with regard to two critical areas of national security policy that proved deeply problematic after 9/11- the treatment of enemy combatants and the scope of government secrecy. In each section, I detail ways in which the Obama administration has tried to distance itself from its predecessor. I also recount actions that could be read as allowing Bush understandings of executive power to persist and explain how the administration seems to be missing, intentionally or not, fairly obvious opportunities to articulate a different conception of a post- $9 / 11$ presidency. In Part IV, I speculate on the reasons for this seeming letdown and set forth what I take to be its potential costs to our governance. It would require a much longer work - albeit one I hope eventually to complete - to set out the alternative vision of executive power that I would wish the administration to embrace. I conclude, however, with at least a brief outline of that vision, which I call "the Democratic Presidency" and which seems entirely consistent with at least President Obama's general pronouncements about legitimacy and the rule of law.

\section{THE DETENTION, TREATMENT, AND TRIAL OF ENEMY COMBATANTS}

The most heated separation of powers controversies surrounding the Bush administration centered on its prosecution of the "War on Terror." At the top of the list were Bush administration claims that the President could hold enemy combatants at Guantánamo Bay without judicial review of their detention; 9 that the President could unilaterally interpret the Geneva Conventions as inapplicable to detainees captured in Afghanistan; ${ }^{10}$ that, for alleged violations of the laws of war, the executive branch could try accused enemy combatants by military commissions without observing constitutional rights implicated in ordinary prosecutions; ${ }^{11}$ and that the President could authorize harsh interrogation techniques regardless of either domestic or international law banning torture. ${ }^{12}$

9. Memorandum from Patrick F. Philbin, Deputy Assistant Att'y Gen., Office of Legal Counsel of the U.S. Dep't of Justice \& John C. Yoo, Deputy Assistant Att'y Gen., Office of Legal Counsel of the U.S. Dep't of Justice, to William J. Haynes II, Gen. Counsel, Dep’t of Def. (Dec. 28, 2001), reprinted in ThE Torture Papers: The Road to Abu Ghraib 29 (Karen I. Greenberg \& Joshua L. Dratel eds., 2005).

10. Memorandum from John Yoo, Deputy Assistant Att'y Gen., Office of Legal Counsel of the U.S. Dep't of Justice, \& Robert J. Delabunty, Deputy Assistant Att'y Gen., Office of Legal Counsel of the U.S. Dep’t of Justice, to William J. Haynes II, Gen. Counsel, Dep’t of Def. (Jan. 9, 2002), reprinted in THE Torture Papers, supra note 9, at 38.

11. Memorandum from Jay S. Bybee, Assistant Att'y Gen., Office of Legal Counsel of the U.S. Dep't of Justice, to William J. Haynes II, Gen. Counsel, Dep't of Def. (Feb. 26, 2002), reprinted in The Torture PApers, supra note 9, at 144.

12. Memorandum from Jay S. Bybee, Assistant Att'y Gen., Office of the Legal Counsel of the U.S. Dep't of Justice, to Alberto Gonzales, Counsel to the President (Aug. 1, 2002), reprinted in The Torture PApers, supra note 9, at 172. 


\section{THE PROSPECTS FOR A DEMOCRATIC PRESIDENCY IN A POST-9/11 WORLD}

The Supreme Court explicitly rebuffed the first three of these positions in a series of three cases: Rasul v. Bush, ${ }^{13}$ Hamdan v. Rumsfeld, ${ }^{14}$ and Boumediene v. Bush ${ }^{15}$ In Rasul the Court held that the general federal habeas corpus statute ${ }^{16}$ applied to Guantánamo detainees. Thus, the petitioners, two Australian and twelve Kuwaiti citizens who were captured in Afghanistan, could all challenge their detention under that statute. ${ }^{17}$

Hamdan, a suit brought pursuant to the federal habeas statute, challenged the permissibility of trying Guantánamo detainees before military commissions. Hamdan was a Yemeni national accused of working as Osama bin Laden's bodyguard and personal driver. ${ }^{18}$ The Court held that the Geneva Conventions apply to detainees in Hamdan's position; that he could enforce their protections through judicial suit; and that Guantánamo military commissions as then constituted fell short of standards imposed by the Geneva Conventions, as implemented by federal statutes. ${ }^{19}$ The Court further held that military commissions could try defendants only for "war crimes" and that the conspiracy charge lodged against Hamdan was not a war crime as defined either by federal or customary international law. ${ }^{20}$

Boumediene, the Supreme Court's most recent Guantánamo decision, returned to the adjudication of enemy combatant status. Congress had reacted to Hamdan by enacting the Military Commissions Act of 2006 (MCA). ${ }^{21}$ The MCA provided a relatively circumscribed process for reviewing administrative determinations that a Guantánamo detainee was, in fact, an enemy combatant. The MCA otherwise eliminated habeas access for non-citizens subject to its provisions. Boumediene held the MCA's bar to habeas unconstitutional. The majority concluded that, unless enemy combatants have access to habeas review of their detention, the determination of enemy combatant status, through a combination of administrative adjudication and judicial oversight, has to provide a fully equivalent substitute to habeas in terms of assuring a sound factual basis for the detention. ${ }^{22}$ The MCA scheme fell short. ${ }^{23}$

\footnotetext{
13. 542 U.S. 466 (2004).

14. 548 U.S. 557 (2006).

15. 553 U.S. 723 (2008).

16. 28 U.S.C. $§ 2241$ (2006).

17. 542 U.S. at 466, 484.

18. 548 U.S. at 570.

19. Id. at $628-29,632,634$.

20. Id. at 563-64.

21. Pub. L. No. 109-366, 120 Stat. 2600 (2006), amended by the Military Commissions Act of 2009, Pub. L. No. 111-84, 123 Stat. 2190, 2574-614 (2009) (codified as amended in scattered sections of 10 U.S.C.).

22. Boumediene v. Bush, 553 U.S. 723, 732-33 (2008).

23. A fourth important loss for the administration was Hamdi v. Rumsfeld, a habeas case involving an alleged enemy combatant who was also a U.S. citizen, 542 U.S. 507 (2004). The Court confirmed that the Authorization to Use Military Force, which Congress enacted after September 11, 2001, gave the President authority to detain enemy combatants captured in fighting against the Taliban and al-Qaeda, irrespective of citizenship. Hamdi, 542 U.S. at 509 (discussing Pub. L. No. 107-40, 115 Stat. 224 (2001)). It held, however, that detention based on alleged enemy combatant status had to be based on administrative
} 
The Supreme Court has not yet been called upon to decide on the fourth of the Bush administration's truly controversial positions-its limited definition of torture and its assertion that Congress lacked the power to regulate the President's power to authorize wartime interrogation techniques. The Court's decisions, however, clearly imply a negative response. First, as noted above, Hamdan held the Geneva Conventions applicable to detainees in the war against al-Qaeda and the Taliban. ${ }^{24}$ Moreover, four concurring Justices in Hamdan-Breyer, Kennedy, Souter, and Ginsburg-specifically wrote, "The Court's conclusion ultimately rests upon a single ground: Congress has not issued the Executive a 'blank check."' 25 This obviously implies congressional power to regulate the President's conduct, and it is doubtful that Justice Sotomayor, who succeeded Justice Souter, or Justice Kagan, the successor to Hamdan's author, Justice Stevens, would disagree.

As of this writing, the Ninth Circuit is deciding an appeal from a decision allowing former Justice Department attorney John Yoo to be sued for his alleged role in sanctioning torture. ${ }^{26}$ Under then assistant attorney general Jack Goldsmith, the Office of Legal Counsel (OLC) actually rescinded the opinions authored by professor Yoo that purported to uphold the President's authority to allow any interrogation techniques he thought appropriate, regardless of applicable statutes. ${ }^{27}$

On its second day in office, the Obama administration distanced itself from the Bush administration's positions on the Geneva Conventions and interrogation techniques and aligned itself explicitly with the Supreme Court's Guantánamo holdings. Executive Order 13,491 asserted the appropriateness of the standards articulated in the Geneva Conventions' Common Article 3 in guiding the conditions of custody for all individuals detained in any armed conflict involving the United States. ${ }^{28}$ It ordered the closing of all secret CIA detention facilities. ${ }^{29}$ It renounced all legal guidance regarding interrogation rendered between September 11, 2001, and January 20, 2009. ${ }^{30} \mathrm{~A}$ companion order created an interagency task force to conduct

procedures meeting constitutional standards of due process-a holding that prompted the Bush administration to create the so-called Combatant Status Review Tribunals (CSRTs) for this purpose. Id.

24. Hamdan, 548 U.S. at 628-29.

25. Id. at 636 (Kennedy, J., concurring).

26. Padilla v. Yoo, 633 F. Supp. 2d 1005 (N.D. Cal. 2009).

27. Memorandum for the Files from Steven G. Bradbury, Principal Deputy Assistant Att'y Gen., Office of Legal Counsel of the U.S. Dep't of Justice (Jan 15, 2009) [hereinafter Bradbury Memo], http://www. justice.gov/olc/docs/memostatusolcopinions01152009.pdf.

28. Exec. Order No. 13,491, § 3(a), 74 Fed. Reg. 4893, 4894 (Jan. 22, 2009).

29. Id. $\S 4$, at 4894 .

30. Id. $\S 1$, at 4893. The Justice Department's Office of Legal Counsel (OLC) had withdrawn several of the relevant opinions under President George W. Bush. Bradbury Memo, supra note 27. OLC withdrew five more under President Barack Obama. Memorandum from David J. Barron, Acting Assistant Att'y Gen., Office of Legal Counsel of the U.S. Dep't of Justice, for the Att'y Gen. (Apr. 15, 2009), http:// www.justice.gov/olc/2009/withdrawalofficelegalcounsel.pdf; Memorandum from David J. Barron, Acting Assistant Att'y Gen., Office of Legal Counsel of the U.S. Dep't of Justice, to the Att'y Gen. (June 11, 2009), http://www.justice.gov/olc/2009/memo-barron2009.pdf. 
THE PROSPECTS FOR A DEMOCRATIC PRESIDENCY IN A POST-9/11 WORLD

a comprehensive review of the lawful options available to the Federal Government with respect to the apprehension, detention, trial, transfer, release, or other disposition of individuals captured or apprehended in connection with armed conflicts and counterterrorism operations, and to identify such options as are consistent with the national security and foreign policy interests of the United States and the interests of justice. ${ }^{31}$

Yet a third executive order articulated the goal of closing Guantánamo within a year ${ }^{32}$ and set in motion a process to review the status of all remaining Guantánamo detainees with an eye toward their transfer to facilities in the United States, prosecution, or possible release. This order specifically referred to "all applicable laws governing the conditions of . . . confinement, including Common Article 3 of the Geneva Conventions." 33 That process yielded a January 2010 Task Force report concerning the 240 then detainees at Guantánamo; 156 were found appropriate for transfer to countries outside the United States, and 36 remained under active investigation for possible prosecution. ${ }^{34}$ That left only 48 detainees in de facto "prisoner of war" status, i.e., "too dangerous to transfer but not feasible for prosecution." 35

On the use of military commissions, President Obama waited until May 2009 before publicly stating that such commissions "are appropriate for trying enemies who violate the laws of war, provided that they are properly structured and administered." ${ }^{36}$ In taking that stance, however, he indicated five respects in which he felt the version of military commissions offered by the Bush administration was inadequate. ${ }^{37}$ Following the President's statement, then secretary of defense Robert M. Gates amended military commission procedures to (1) prohibit the admission of statements obtained through cruel, inhuman, and degrading treatment; (2) give detainees greater latitude in their choice of counsel; (3) afford protection for those defendants who refuse to testify; (4) place the burden of justification for using hearsay on the party trying to use it; and (5) confirm that military judges are empowered to

31. Exec. Order No. 13,493, § 1(e), 74 Fed. Reg. 4901, 4901 (Jan. 22, 2009).

32. Exec. Order No. 13,492, § 3, 74 Fed. Reg. 4897, 4898 (Jan. 22, 2009).

33. Id. $\S 6$, at 4899 .

34. U.S. Dep’t of Justice, et al., Final Report of the Guantánamo Review Task Force, at ii (2010), http://www.justice.gov/ag/guantanamo-review-final-report.pdf. Of the 156 detainees found appropriate for transfer to countries outside the United States, "30 detainees from Yemen were designated for 'conditional' detention based on the current security environment in that country. They are not approved for repatriation to Yemen at this time, but they may be transferred to third countries, or repatriated to Yemen in the future ...." Id.

35. Id.

36. President Barack Obama, Statement of President Barack Obama on Military Commissions (May 15, 2009), available at http://www.whitehouse.gov/the-press-office/statement-president-barack-obamamilitary-commissions.

37. Id. 
determine their own jurisdiction. ${ }^{38}$ In October 2009 President Obama signed into law the Military Commissions Act of 2009, ${ }^{39}$ which made all five changes statutory.

In all of these respects, therefore-acknowledging the availability of habeas review, applying the Geneva Conventions to all military detainees, renouncing the use of harsh interrogation techniques, and increasing the procedural protections entailed in military commissions- the Obama administration embraced positions that the Bush administration initially resisted. Attorney General Eric Holder further asserted the appropriateness of trying terrorist suspects, whenever possible, in Article III federal courts, pushing back against political pressure to try all alleged enemy combatants exclusively in military venues. ${ }^{40}$ Subjecting terrorists to prosecution and punishment within the ordinary criminal justice system is itself a form of allegiance to the rule of law. These are not small matters. And, in announcing these policy changes, President Obama adverted explicitly, albeit summarily, to critical values such as "the safe, lawful, and humane treatment of individuals in United States custody,"41 "the interests of justice," ${ }^{\prime 42}$ and "the rule of law."

Yet, none of the relevant documents or accompanying presidential statements offers any critique of the Bush theories of presidential authority that underpinned the earlier administration's stance on habeas corpus, military commissions, or the interrogation and confinement of alleged enemy combatants. There has not been a statement elaborating on what the President takes to be the demands of the "rule of law" regarding the exercise of executive authority, or the ways in which "our deeply held values" will be balanced against America's "national security interests."

In the absence of such statements, there stand several conspicuous points of operational continuity between Bush and Obama policy that please Bush supporters and trouble Bush critics: the detention of alleged enemy combatants without any legal protections at Bagram Air Force Base in Afghanistan, ${ }^{44}$ the continued use of military commissions for trying enemy combatants for war crimes, ${ }^{45}$ and the indefinite incarceration of at least some military detainees without trial. ${ }^{46}$ There also has emerged a controversy, not raised to public attention during the Bush administration,

38. Id.; Jennifer K. Elsea, Cong. Research Serv., R 41163, The Military Commissions Act of 2009: Overview of Legal Issues 3 (2009), http://www.fas.org/sgp/crs/natsec/R41163.pdf.

39. Military Commissions Act of 2009, Pub. L. No. 111-84, 123 Stat. 2190, 2574-614 (2009) (codified as amended in scattered sections of 10 U.S.C.).

40. Eric Holder, Attorney General Eric Holder Speaks at the U.S. Constitution Project Awards Dinner (Apr. 15, 2010), available at http://www.justice.gov/ag/speeches/2010/ag-speech-1004152.html.

41. Exec. Order No. 13,491, supra note 28, at 4893.

42. Exec. Order No. 13,492, supra note 32, at 4897.

43. Obama Nat'1 Sec. Remarks, supra note 7.

44. William Fisher, Bagram's "New" Rules. So What's New?? Huffington Post (Sept. 14, 2009), http:// www.huffingtonpost.com/william-fisher/bagrams-new-rules-so-what_b_285638.html.

45. Peter Finn, Detainee Khadr Pleads Guilty, Wash. Post, Oct. 26, 2010, at A06, available at http://www. washingtonpost.com/wp-dyn/content/article/2010/10/25/AR2010102505473.html.

46. U.S. Dep't of Justice, et al., supra note 34 , at 12. 


\section{THE PROSPECTS FOR A DEMOCRATIC PRESIDENCY IN A POST-9/11 WORLD}

that has plainly vexed progressive critics of President Obama's predecessor: whether (and in what form) the President is bound by constitutional requirements of due process before consigning a U.S. citizen to a CIA "kill-or-capture" list. This particular controversy over targeted killing arose after the Los Angeles Times reported in April 2010 that the Obama administration had authorized the capture or killing of Anwar al-Aulaqi ${ }^{47}$ a Muslim cleric born in New Mexico to Yemeni parents. ${ }^{48}$

Al-Aulaqi's father subsequently brought suit, as his son's putative "next friend," seeking to enjoin the intentional killing of his son outside an armed conflict, unless he poses an imminent threat to life or physical safety and no less draconian measures are available to neutralize his threat. ${ }^{49}$ In its opposition brief, the administration characterizes al-Aulaqi as follows:

Anwar al-Aulaqi is a dual U.S.-Yemeni citizen and a leader of al-Qaeda in the
Arabian Peninsula (AQAP), a Yemen-based terrorist group that has claimed
responsibility for numerous armed terrorist attacks against American, Saudi
Arabian, Korean and Yemeni targets since January 2009. [He] has recruited
individuals to join AQAP, facilitated training at camps in Yemen in support
of acts of terrorism, and helped focus AQAP's attention on attacking U.S.
interests. In addition, since late 2009, Anwar al-Aulaqi has taken on an
increasingly operational role in AQAP, including preparing Umar Farouk
Abdulmutallab in his attempt to detonate an explosive device aboard a
Northwest Airlines flight from Amsterdam to Detroit on Christmas Day
2009. The United States has further determined that AQAP is an organized
armed group that is either part of al-Qaeda, or is an associated force, or
cobelligerent, of al-Qaeda that has directed armed attacks against the United
States in the noninternational armed conflict between the United States and
al-Qaeda that the Supreme Court recognized in Hamdan $v$. Rumsfeld.

These facts appear to be uncontradicted. The Obama administration urged dismissal of the suit on a variety of grounds, including the father's alleged lack of standing, the nonjusticiability of the questions posed, the court's equitable discretion to deny relief, and the lack of a cause of action under the Alien Tort Statute. ${ }^{51}$ The administration also asserted, as a final ground for dismissing the suit-a ground it explicitly and successfully urged the Court not to reach—that litigating the father's claim would

47. In both official documents and journalistic accounts, "Aulaqi" is variously spelled "Aulaqi," "Awlaqi," and "Awlaki." I am using "Aulaqi," as reflected in court documents, except where quoting from a text that uses a different spelling.

48. David S. Cloud, Awlaki is Added to CIA Target List, L.A. Times, Apr. 7, 2010, at 8, available at http:// articles.latimes/com/2010/apr/06/world/la-fg/yemen-cleric7-2010apr07.

49. Memorandum in Support of Plaintiff's Motion for a Preliminary Injunction at 1, 10, Al-Aulaqi v. Obama, 727 F. Supp. 2 d 1 (D.D.C. 2010) (No. 10-cv-1469), 2010 WL 3555385, at *2, *6.

50. Opposition to Plaintiff's Motion for Preliminary Injunction and Memorandum in Support of Defendants' Motion to Dismiss at 1, Al-Aulaqi v. Obama, 727 F. Supp. 2 d 1 (D.D.C. 2010) (No. 10-cv1469), 2010 WL 3863135, at *2.

51. Id. at 9-42. 
entail the disclosure of information protected by the state secrets privilege. ${ }^{52}$ Not surprisingly, upon the filing of the government's brief, the New York Times headline read: "State Secrets Cited in Effort by White House to Block Suit." 53 A widely read progressive reporter summarized the oral argument as follows: "Lawyers for the Barack Obama administration told a federal judge ... that the U.S. government has authority to kill U.S. citizens whom the executive branch has unilaterally determined pose a threat to national security." ${ }^{4}$

It is not difficult to imagine why Anwar al-Aulaqi would be targeted for a killor-capture list. What seems striking, however-especially in light of the campaign theme of "change"-is the administration's apparent decision not to discuss in any detail its operating standards, its decisionmaking processes, or their application to al-Aulaqi. Outside the litigation, the administration's sole public stance seems to have been articulated in a briefing with then White House press secretary Robert Gibbs. It is worth considering the exchange as a whole, in order to see why the administration's critics see so little change from the Bush administration:

Q: Human rights lawyers are challenging the administration's assertion that an American citizen can be targeted for killing overseas. Should Americans worry that if they go overseas, their own government could target them to be killed? Anwar al-Awlaki is the person in question, but the legal principle-

MR. GIBBS: Okay, let's-let me just for the point of-I don't know what I would make-I think you just largely said a tourist going overseas and Anwar al-Awlaki are somehow analogous in nature. I'm not a-

Q: But if the U.S. decides that an American citizen is affiliated with a terrorist group-

MR. GIBBS: No, no, let's be clear, let's be-no, no, let's be clear.

$\mathrm{Q}$ : Is there any legal process?

MR. GIBBS: Let's be clear about Anwar al-Awlaki, okay? The United States hasn't decided that Anwar al-Awlaki is aligned with a terrorist group. Anwar al-Awlaki has in videos cast his lot with al Qaeda and its extremist allies. Anwar al-Awlaki is acting as a regional commander for al Qaeda in the Arabian Peninsula. So let's not take a tourist that might visit Italy overseas and equate him to somebody who has on countless times in video pledged to uphold and support the violent and murderous theories of al Qaeda. There-

Q: The U.S. has mistakenly identified people as terrorists in many instances in the last eight years, and if Americans can be targeted for killing-

52. Id. at $43-59$.

53. Charlie Savage, State Secrets Cited in Effort by White House to Block Suit, N.Y. Times, Sept. 25, 2010 at 7, available at http://www.nytimes.com/2010/09/25/world/25awlaki.html.

54. William Fisher, Obama Lawyers Defend "Kill Lists," Inter Press Service News Agency (Nov. 9, 2010), http://ipsnews.net/news.asp?idnews=53508. 
THE PROSPECTS FOR A DEMOCRATIC PRESIDENCY IN A POST-9/11 WORLD

MR. GIBBS: Ari, it's hard to imagine an issue in which two things have been conflated more than your question in the past 18 months of me taking questions here. I think the notion that somehow anybody in this country confuses traveling overseas and the role that Anwar al-Awlaki has in inciting violence-they're not even in the same ballpark.

Q: Are you acknowledging that Awlaki is on the assassination list, then?

MR. GIBBS: I just answered his question about comparing Joe the Tourist to Anwar al-Awlaki.

Q: Just a quick follow to that. U.S. citizens are entitled to a certain judicial process when it comes to questions like this, when it comes to sentencing to death. And is there a process in place that we don't know about?

MR. GIBBS: There's a process in place that I'm not at liberty to discuss.

Q: [T]here is a lawsuit that the Center for Constitutional Rights and the ACLU is bringing today regarding the policies or lack-perceived lack of policies as they relate to Mr. al-Awlaki. And what I wanted to ask is-I mean, you just told us there is a process in place that you're not at liberty to discuss. Is that going to be the government's position, or are you going to disclose what the policy is? Do you think there's any merit to this lawsuit?

MR. GIBBS: Well, look, again, there is-I'm just not at liberty to discuss intelligence matters, Margaret. I would say-I will repeat that Anwar al-Awlaki is someone who has sworn allegiance to al Qaeda in the Arabian Peninsula, is a regional commander for that group in Yemen, has and continues to direct attacks there and, as we know, against innocent men, women and children in this country. And this President will take the steps necessary to keep our country safe from thugs like him.

Q: I understand that. But the President is also a lawyer with constitutional law training. He made clear during the campaign that sort of dotting the i's and crossing the t's mattered, even if you're going after bad guys.

MR. GIBBS: And I think it's safe to assume that if-without getting deep into this - the President understands the process and the President will do all that is necessary to keep this country safe from people like him. ${ }^{55}$

To his credit, Mr. Gibbs nowhere says that the President has inherent constitutional authority to kill at-will any American whom the President perceives to be a threat to national security. But note how the press secretary dodges the substance of every question. The reporter asks about the administration's position regarding Americans who "go overseas." Gibbs limits the question to "tourists," and then

55. Press Briefing by Press Sec'y Robert Gibbs (Aug. 3, 2010), available at http://www.whitehouse.gov/thepress-office/press-briefing-press-secretary-robert-gibbs-832010. 
belittles the hypothetical. He says he cannot discuss the relevant decisionmaking process, but that Mr. Obama "understands the process," and that the President "will do all that is necessary" to protect the United States against al-Aulaqi and his ilk. He simply refuses to engage the question whether there is any tension between the handling of the al-Aulaqi matter and the President's campaign stance. To anyone critical of Bush administration positions on presidential authority, the Gibbs defense - and, to some extent, even the more carefully argued administration position urged in the al-Aulaqi case-seem to echo the President's post-midterm acknowledgment, quoted above: "[W]e were in such a hurry to get things done that we didn't change how things got done."

By way of contrast, as a "thought experiment," imagine an administration that explains the principles behind its decisionmaking in a way that clarifies the administration's allegiance to the rule of law:

Following September 11, Congress authorized the President to use "all necessary and appropriate force" against those organizations that "committed ... the [September 11] terrorist attacks ... . in order to prevent any future acts of international terrorism against the United States by such . . . organizations." ${ }^{156}$ Anwar al-Aulaqi is a leader of al-Qaeda in the Arabian Peninsula (AQAP), an organized armed group that is either part of al-Qaeda, or an associated force, or cobelligerent, of al-Qaeda that has directed armed attacks against the United States. From the evidence available to us, there is no doubt that Mr. al-Aulaqi, if physically present in the United States, would be subject to lawful apprehension by federal authorities. The problem is, he is not in the United States. Therefore, the tools available to us of "necessary and appropriate force" to mitigate the threat of attacks on the United States by Mr. al-Aulaqi are not the tools of ordinary law enforcement.

The Constitution prohibits this government from depriving any person of life or liberty without due process. As an American citizen, Mr. al-Aulaqi enjoys this protection, wherever he may be. The Supreme Court has stated, however, that due process "is not a technical conception with a fixed content unrelated to time, place and circumstances. ${ }^{57}$ Without confirming or denying any decision that has been made with regard to Mr. al-Aulaqi, what we believe due process requires in cases like his is a course of fact-finding within the executive branch that is exceptional in its rigor and intensity. Congress having created no judicial review process for cases such as this, we proceed on our own initiative. In exercising that initiative, we proceed based only on evidence as compelling as the seriousness of our contemplated action may warrant.

In just two hypothetical paragraphs, the administration could make clear five things that Mr. Gibbs's response either obfuscates or ignores. First, the President is proceeding based on statutory authority. Second, the executive branch distinguishes between Americans abroad and Americans on home territory. Third, due process applies to Mr. al-Aulaqi. Fourth, the executive branch does not seek judicial review

56. Authorization for Use of Military Force, Pub. L. 107-40, § 2, 115 Stat. 224, 224 (2001).

57. Mathews v. Eldridge, 424 U.S. 319, 334 (1976). 
THE PROSPECTS FOR A DEMOCRATIC PRESIDENCY IN A POST-9/11 WORLD

of its determinations to use force because no such review is available. (The President would not have to say in what circumstances, if any, he thinks Congress could or should constitutionally authorize such review.) Fifth, the executive regards itself as constitutionally bound to follow a fact-finding process of utmost care in dealing with the use of potentially fatal force against a U.S. citizen, even one who has taken up arms against the United States. Although I have no inside knowledge, I am confident that the positions I have posited here are actually aligned with most of the administration's legal thinking. Thus, failing to articulate something like the script I have imagined strikes me as a perfect example of what looks like the Obama administration's hesitancy, unwillingness, or inability to tie controversial decisions to its larger beliefs-in this case, beliefs in due process, the rule of law, and checks and balances in the management of national security. The absence of such a statement creates ambiguity about the administration's stance on presidentialism that some critics, otherwise politically sympathetic to the administration, understandably bemoan.

\section{GOVERNMENT SECRECY}

Another manifestation of the Bush administration's belief in the President's narrow accountability was its frequent insistence on secrecy. For fiscal years 2002 through 2004, there were dramatic increases in the number of pages of classified documents and corresponding decreases in the number of pages declassified. ${ }^{58}$ Large numbers of documents and databases were removed from government websites. ${ }^{59}$ There was a notable jump in refusals to disclose records requested by members of the public under the Freedom of Information Act (FOIA), even though the number of times agencies relied on national security exemptions to FOIA dropped. ${ }^{60}$ Former vice president Dick Cheney litigated relentlessly to fend off public disclosure of who in the oil industry had met with his task force to develop the administration's legislative proposals on energy. ${ }^{61}$ Perhaps oddest of all was a November 1, 2001, executive order concerning the government's handling of presidential records from prior administrations - an order that, among other things, purported to allow the family of a disabled former President to choose a personal representative who might claim executive privilege in the name of that President, ${ }^{62}$ a claim that the order supposedly made binding on the National Archivist regardless of the views of the incumbent President. ${ }^{63}$

58. Info. Sec. Oversight Office, 2005 Report to the President 13 (2006), http://www.archives.gov/ isoo/reports/2005-annual-report.pdf.

59. John Podesta, Need to Know: Governing in Secret, in A Little Knowledge: Privacy, Security and Public Information After September 11, at 11, 13-14 (Peter M. Shane, et al. eds., 2004).

60. See Coal. of Journalists for Open Gov't, Federal Government Continues to Fall Behind In Responding to FOIA Requests, CJOG Finds 1-3 (2006), http://www.cjog.net/documents/.pdf.

61. Cheney v. U.S. District Court, 542 U.S. 367, 372 (2004).

62. Exec. Order No. 13,233, § 10, 66 Fed. Reg. 56,025, 56,028 (Nov. 1, 2001).

63. Id. § $3(\mathrm{~d})(1)$ at $56,026-27$. 
As it did with regard to Guantánamo, the Obama administration took a number of early steps to distance itself in both philosophy and practice from the Bush administration in relation to releasing information. On his first full day in office, President Obama devoted his first executive order to rescinding the Bush executive order on the control of records from prior administrations and replacing it with a system far less aggressive in its accommodation of executive privilege claims. ${ }^{64} \mathrm{He}$ likewise issued a memorandum pledging "an unprecedented level of openness in Government." ${ }^{55}$ The memo
direct[s] the Chief Technology Officer, in coordination with the Director of the Office of Management and Budget (OMB) and the Administrator of General Services, to coordinate the development by appropriate executive departments and agencies, within 120 days, of recommendations for an Open Government Directive, to be issued by the Director of OMB, that instructs executive departments and agencies to take specific actions implementing the principles set forth in this memorandum. ${ }^{66}$

A presidential memorandum on FOIA implementation, also issued on January 21, 2009, announced the policy position: "All agencies should adopt a presumption in favor of disclosure, in order to renew their commitment to the principles embodied in [the] FOIA, and to usher in a new era of open Government. The presumption of disclosure should be applied to all decisions involving FOIA." ${ }^{\prime 7}$ President Obama directed "the Attorney General to issue new guidelines governing the FOIA to the heads of executive departments and agencies, reaffirming the commitment to accountability and transparency, and to publish such guidelines in the Federal Register." ${ }^{18}$ On March 19, 2009, Attorney General Holder issued his directive. He rescinded a 2001 policy promulgated by former attorney general John Ashcroft that committed the Department of Justice (DOJ) in almost all cases to defend decisions to withhold records if supported by a "sound legal basis." ${ }^{69}$ It provided, instead, that the DOJ would "defend a denial of a FOIA request only if (1) the agency reasonably foresees that disclosure would harm an interest protected by one of the statutory exemptions, or (2) disclosure is prohibited by law." ${ }^{\prime 0}$ The requirement of actual harm

64. Exec. Order No. 13,489, § 4, 74 Fed. Reg. 4669, 4670 (Jan. 21, 2009).

65. Memorandum on Transparency \& Open Gov't from the President to the Heads of Exec. Dep'ts \& Agencies, 74 Fed. Reg. 4685, 4685 (Jan. 21, 2009).

66. $I d$.

67. Memorandum on Freedom of Info. Act from the President for the Heads of Exec. Dep'ts \& Agencies, 74 Fed. Reg. 4683, 4683 (Jan. 21, 2009).

68. $I d$.

69. Memorandum from Att'y Gen. Eric Holder, Dep't of Justice, to the Heads of Exec. Dep'ts \& Agencies 1-2 (Mar. 19, 2009), http://www.justice.gov/ag/foia-memo-march2009.pdf.

70. Id. at 2 . 


\section{THE PROSPECTS FOR A DEMOCRATIC PRESIDENCY IN A POST-9/11 WORLD}

aligned the Holder Justice Department's FOIA policy with those of the Carter and Clinton administrations. ${ }^{71}$

There's no doubt that these position shifts have been accompanied by at least some important concrete actions that distance the Obama administration from the Bush administration. In February 2009 the Obama Defense Department lifted the ban on photographing the coffins of returning war dead from Iraq and Afghanistan. ${ }^{72}$ In September 2009 the White House agreed to post its visitor logs online, containing information on all but a few narrow categories of visitors to the President or Vice President. ${ }^{73}$ In December 2009 President Obama issued an executive order that not only shifted the standards for handling national security information in the direction of greater access, but also created a National Declassification Center in the National Archives. ${ }^{74}$ The Center's mandate is to achieve by December 31, 2013, public access to all properly declassified records within a backlog of over 400 million pages of records that have been withheld so far from automatic declassification. ${ }^{75}$ In January 2010 the administration released the names of detainees at the Bagram Air Force Base in Afghanistan. ${ }^{76}$

In late 2009, intelligence agencies also began to disgorge records that the Electronic Freedom Foundation had requested from the Bush administration documenting agency misconduct. These encompassed, for example, a Defense Department document release including

A report that the Joint Forces Command, working with the FBI, improperly collected and disseminated intelligence on Planned Parenthood and a white supremacist group called the National Alliance, as part of preparations for the 2002 Olympics.

A North American Aerospace Defense Command (NORAD) briefing improperly included intelligence on an antiwar group called Alaskans for Peace and Justice in $2005 \ldots$. . .

A report from 2003 of a closed investigation into prisoner abuse at Abu Ghraib and other sites in Iraq .... [and]

71. See Jerry L. Mashaw, Richard A. Merrill \& Peter M. Shane, Administrative Law: The American Public Law System 768 (6th ed. 2009).

72. Martin Sieff, Photo ban on Iraq war dead lifted, UPI.com (Feb. 27, 2009), http://www.upi.com/news/ issueoftheday/2009/02/27/Photo-ban-on-Iraq-war-dead-lifted/UPI-33241235755703.

73. White House Voluntary Disclosure Policy: Visitor Access Records, WhiteHouse.gov (Sept. 4, 2009), http:// www.whitehouse.gov/VoluntaryDisclosure.

74. Exec. Order No. 13,526, § 3.7, 75 Fed. Reg. 707, 719 (Dec. 29, 2009).

75. Memorandum on Implementation of the Exec. Order, "Classified Nat'1 Sec. Info.," from the President to the Heads of Exec. Dep'ts \& Agencies, 75 Fed. Reg. 733 (Dec. 29, 2009).

76. Alissa J. Rubin \& Sangar Rahimi, U.S. Military Names 645 Detainees Held at Key Afghanistan Base, N.Y. Times, Jan. 16, 2010, at A6, available at http://www.nytimes.com/2010/01/17/world/asia/17afghan. html. 
A 2008 report that Army Signals Intelligence in Louisiana intercepted civilian cell phone conversations. ${ }^{77}$

Such initiatives were all taken in addition to a variety of ambitious government-wide transparency measures implementing the Office of Management and Budget's Open Government Directive, which was finally issued on December 8, 2009. ${ }^{78}$

In September 2009 the administration adopted a new policy and set of procedures aimed at limiting both the invocation of the so-called state secrets privilege and the consequences for public accountability when the privilege is invoked. Specifically, under a new Justice Department policy, the attorney general committed the Justice Department to invoking the privilege to prevent only "significant" harm to national security. ${ }^{79} \mathrm{He}$ pledged that the privilege would not be invoked to conceal violations of law or merely embarrassing behavior. ${ }^{80}$ Should any agency wish the privilege to be invoked on its behalf, it must now provide to the Justice Department a detailed justification, which, in turn, must be endorsed by the assistant attorney general (AAG) in charge of the relevant litigating division. Should the AAG recommend invocation, that recommendation would be reviewed by a newly constituted State Secrets Review Committee, whose recommendation, in turn, would go to the deputy attorney general and, if approved, to the attorney general. The privilege is not to be invoked without the attorney general's sign-off. The attorney general, if he or she invokes the privilege, is to report the matter to the relevant agency inspector general should the attorney general find plausible the underlying assertions of wrongdoing.

Despite the new procedure, however, the administration has persisted in invoking the state secrets privilege in litigation aimed at establishing accountability for alleged violations of law by the Bush administration. Prior to the elaboration of the attorney general's new policy, the Holder Justice Department had already invoked the state secrets privilege to secure the dismissal of suits related to the Bush administration's extraordinary renditions ${ }^{81}$ and the Terrorist Surveillance Program (TSP) ${ }^{82}$ - the program of warrantless electronic surveillance conducted by the NSA in apparent defiance of the Foreign Intelligence Surveillance Act. ${ }^{83}$ Even with the new policy in place, the administration has continued to invoke the privilege in new TSP-related

77. William Fisher, DoD Releases Records of Illegal Surveillance, Truth-Out (Mar. 3, 2010), http://archive. truthout.org/dod-releases-records-illegal-surveillance57329.

78. Memorandum from Peter R. Orszag, Dir., Office of Mgmt. \& Budget, to the Heads of Exec. Dep'ts \& Agencies (Dec. 8, 2009), http://www.whitehouse.gov/omb/assets/memoranda_2010/m10-06.pdf.

79. Memorandum from Att'y Gen. Eric Holder, Dep't of Justice, to Heads of Exec. Dep'ts \& Agencies 1 (Sept. 23, 2009), www.justice.gov/opa/documents/state-secret-privileges.pdf.

80. Id. at 2 .

81. Mohamed v. Jeppesen Dataplan, Inc., 614 F.3d 1070, 1076-77 (9th Cir. 2010) (en banc).

82. See, e.g., In re Nat'1 Sec. Agency Telecomm. Records Litig., 700 F. Supp. 2 d 1182 (N.D. Cal. 2010); see also Al-Haramain Islamic Found., Inc. v. Bush, 451 F. Supp. 2d 1215 (D. Or. Sep 07, 2006), rev'd, 507 F.3d 1190 (9th Cir. 2007), on remand to sub nom, In re Nat'l Sec. Agency Telecomm. Records Litig., 564 F. Supp. 2d 1109 (N.D. Cal. 2008).

83. See 50 U.S.C. $§ 1801$ (Supp. IV 2010). 


\section{THE PROSPECTS FOR A DEMOCRATIC PRESIDENCY IN A POST-9/11 WORLD}

litigation. ${ }^{84}$ This stance is all the more notable, of course, because candidate Obama was critical of the Terrorist Surveillance Program, ${ }^{85}$ and President Obama, early on, directed an end to the practice of extraordinary rendition. ${ }^{86}$ In stymying litigation involving extraordinary renditions and the TSP, the Obama administration appears to be thwarting the very value of government accountability that it adopted with much fanfare as its operating watchword.

As with its conduct on the substantive aspects of antiterrorism policy, we see again a seeming reluctance by the Obama administration to connect its stance on state secrets with larger ideas about executive power and public accountability. To be sure, the Holder September 2009 policy statement seeks to place state secrets determinations within a sensible values framework. It foreswears use of the privilege to protect information unless the release of that information would work significant harm to national security. ${ }^{87}$ It promises to use the privilege as the basis for seeking dismissal of a case or claim only when continued pursuit of the case or claim would portend such harm. The policy gestures towards accountability by committing the attorney general to seek inspector general investigations of any claims raised, whichalthough opposed in court on state secrets grounds-nonetheless raise "credible allegations of government wrongdoing." ${ }^{8}$ Unfortunately, in terms of distancing the Obama administration from the Bush administration's excesses, there is no way of knowing whether this policy makes any operational difference at all.

Of course, it is possible that the policy is doing just the job it should. For all we know, when the state secrets privilege has been invoked by the Obama administration, the government lawyers involved, including the attorney general, may have been appropriately persuaded by their client agencies that the disclosure of the disputed material would, indeed, work significant harm to the national security or foreign policy interests of the United States. For all we know, the process outlined has led to the rejection of some potential state secrets claims that would have been raised by other administrations. For all we know, it may even be that the policy has resulted in internal investigations that are rooting out government wrongdoing. The problem is, of course, that we know nothing. The Obama administration has not made a public case for any of this - a silence that continues to fuel claims on both the left and right that, on matters of government secrecy in the national security area, there is no meaningful difference between the Obama administration and its predecessor.

84. Justin Elliott, Obama Adopts Bush's State Secrets Position-And Exact Language-In NSA Spying Case, Talking Points Memo (Nov. 2, 2009, 6:03 PM), http://tpmmuckraker.talkingpointsmemo.com/ 2009/11/obama_adopts_bushs_state_secrets_position_--_and_e.php.

85. Anne Broache, Obama: No warrantless wiretaps if you elect me, CNET News (Jan. 8, 2008, 1:16 PM), http://news.cnet.com/8301-10784_3-9845595-7.html.

86. Exec. Order No. 13,491, 74 Fed. Reg. 4893, 4895 (2009).

87. Memorandum from Att'y Gen. Eric Holder, Dep't of Justice, to the Heads of Exec. Dep'ts \& Agencies, supra note 79 , at 1 .

88. Id. at 3 . 
Indeed, in the public mind - and certainly, in the mind of its critics-the proper frame for understanding the administration's stance on state secrets is not its assertedly robust commitment to openness in other contexts, but rather its apparent unwillingness to hold anyone accountable for the abuses of the Bush administration. Thus, for example, the administration has declined to pursue discipline against Justice Department attorneys who provided written advice "riddled with weird arguments, cherry-picked quotations, and inexplicable omissions," ${ }^{\prime 9}$ which provided legal cover for torture..$^{90}$ It has declined to prosecute CIA personnel who destroyed videotapes showing the CIA's interrogation of al-Qaeda members. ${ }^{91}$ It has resisted the idea of an independent commission to look broadly at the rule of law under the Bush administration. ${ }^{92}$ It has even opposed a FOIA suit aimed at obtaining the names of lobbyists who met with government officials to push for a grant of legislative immunity for telecommunications companies that collaborated with the Bush administration in warrantless electronic surveillance in violation of the Foreign Intelligence Surveillance Act. ${ }^{93}$ In the meantime, other nations have exercised the initiative to apologize and compensate their citizens for harms they suffered due to Bush administration policies. ${ }^{94}$

89. David Luban, David Margolis is Wrong, Slate (Feb. 22, 2010, 11:49 AM), http://www.slate.com/ id/2245531/pagenum/all.

90. See Memorandum from David Margolis, Assoc. Deputy Att'y Gen., to the Att'y Gen. \& Deputy Att'y Gen. 3 (Jan. 5, 2010) [hereinafter Margolis Memo], http://judiciary.house.gov/hearings/pdf/ DAGMargolisMemo100105.pdf.

91. Carrie Johnson, No Charges in Destruction of CIA Interrogation Tapes, NPR (Nov. 9, 2010), http://www. npr.org/templates/story/story.php?storyId=131184938.

92. I know that these debates [about actions of the Bush administration] lead directly, in some cases, to a call for a fuller accounting, perhaps through an independent commission.

I've opposed the creation of such a commission because I believe that our existing democratic institutions are strong enough to deliver accountability. The Congress can review abuses of our values, and there are ongoing inquiries by the Congress into matters like enhanced interrogation techniques. The Department of Justice and our courts can work through and punish any violations of our laws or miscarriages of justice.

It's no secret there is a tendency in Washington to spend our time pointing fingers at one another. And it's no secret that our media culture feeds the impulse that lead[s] to a good fight and good copy. But nothing will contribute more than that than a extended relitigation of the last eight years. Already, we've seen how that kind of effort only leads those in Washington to different sides to laying blame. It can distract us from focusing our time, our efforts, and our politics on the challenges of the future.

Obama Nat'1 Sec. Remarks, supra note 7, at 10-11.

93. Elec. Frontier Found. v. Office of the Dir. of Nat'l Intelligence, 595 F.3d 949 (9th Cir. 2010), amended by 639 F.3d 876 (9th Cir. Apr. 9, 2010).

94. William Fisher, Britain to Settle Rendition, Torture Case for Millions, Inter Press Service News Agency (Nov. 16, 2010), http://ipsnews.net/news.asp?idnews=53576; Doug Struck, Tortured Man Gets Apology from Canada, WAsh. Post, Jan. 27, 2007, at A14, available at http://www.washingtonpost.com/ wp-dyn/content/article/2007/01/26/AR2007012601717.html. 
THE PROSPECTS FOR A DEMOCRATIC PRESIDENCY IN A POST-9/11 WORLD

It has been reported that Attorney General Holder is not himself entirely pleased with this record. ${ }^{95} \mathrm{He}$ appointed a special counsel to look into possible acts of torture directed at U.S. detainees ${ }^{96}$ - albeit excluding any cases where interrogation techniques were consistent with the Justice Department's earlier legal advice. ${ }^{97}$ It is not clear, however, that the Attorney General enjoys White House support for even this modest initiative. Perhaps referring to President Obama's remarks resisting investigation by an independent commission, ${ }^{98}$ former White House chief of staff Rahm Emanuel is reported to have reacted: "Didn't [Holder] get the memo that we're not re-litigating the past?" 99 The problem with this reaction, however, is that significant aspects of the past have never been litigated at all, much less re-litigated. Attempting to clean up prior abuses without any clear record of what they were, who committed them, or why they actually amounted to abuses under the law, leaves intact and unchallenged the historical precedent set by the prior administration's abuse of power.

Following revelations of massive, illegal domestic intelligence operations during the Nixon administration, the United States had the benefit of high-level investigations by the Rockefeller Commission, appointed by President Gerald Ford, and by the House and the Senate, chaired by Representative Otis Pike and Senator Frank Church, respectively. ${ }^{100}$ The exhaustive report of the Church Committee ${ }^{101}$ is credited with lending impetus to both the reorganization of intelligence oversight in Congress and eventual enactment of the Foreign Intelligence Surveillance Act. Perhaps even more importantly, it created a historical record that Americans thereafter could rely on as a basis for democratic debate about national security and intelligence gathering. It represented checks and balances at their best.

By contrast, in the wake of the Bush administration, we largely have obscurity and evasion with regard to both the conduct of torture and the massive, unlawful disregard of the law on electronic surveillance. Professor David Cole thus sees the

95. See Wil S. Hylton, Hope. Change. Reality., GQ Dec. 2010, at 180, available at http://www.gq.com/ news-politics/politics/201012/eric-holder-attorney-general-rahm-emanuel-white-house-elections; Jane Mayer, The Trial: Eric Holder and the Battle over Khalid Sheikh Mohammed, The New Yorker, Feb. 15, 2010, at 52, available at http://www.newyorker.com/reporting/2010/02/15/100215fa_fact_mayer.

96. Carrie Johnson, Prosecutor to Probe CIA Interrogations, WAsh. Post, Aug. 25, 2009, at A05, available at http://www.washingtonpost.com/wp-dyn/content/article/2009/08/24/AR2009082401743.html.

97. Hylton, supra note 95, at 188.

98. Obama Nat'l Sec. Remarks, supra note 7, at 11.

99. Mayer, supra note 95.

100. Peter M. Shane \& Harold H. Bruff, Separation of Powers Law: Cases and Materials 73740 (3d ed. 2011).

101. Final Report of the Senate Select Comm. to Study Governmental Operations with Respect to Intelligence Activities, S. Rep. No. 94-755 (1976). 
Obama administration as complicit in "our collective failure to confront the wrongs of the past." 102 In Cole's words:

As long as we fail to look back, ... the future of our policies regarding "enemy combatants" . . . will continue to be tainted, encased in soundproof glass, a secret hidden from no one but ourselves. Successfully restoring the rule of law in our struggle against terrorism may not require the release of all detainees held without criminal conviction, but it does require accountability for the crimes committed by some of the United States' highest officials. ${ }^{103}$

In its handling of state secrets, as with its handling of other aspects of national security policy, the administration seems to be missing opportunities to re-articulate the role of the federal executive in a post-9/11 world.

\section{PRAGMATISM AND NARRATIVES OF THE PRESIDENCY IN THE WAKE OF SEPTEMBER 11}

The Obama administration began with a number of express statements of philosophical disagreement with how the Bush administration exercised executive power. Its record reinforces this rhetorical distance from the Bush administration with some important changes in government behavior, but it also reveals a number of continuing, controversial operations in what seems like the Bush mode. These points of continuity, whether the continued use of military commissions or the continued invocation of the state secrets privilege to ward off judicial inquiries into torture and warrantless surveillance, cannot help but cast doubt on the significance of the rhetoric and dishearten the President's political supporters. They also risk implicitly ratifying the ideology of governance that reigned during the Bush-Cheney administration.

This state of affairs is not inevitable. Differences between the two administrations' philosophies are undoubtedly most conspicuous when the Obama administration makes operational decisions plainly at odds with the likely approach of the Bush administration. But it may well be the case that specific decisions made by the Obama administration - even when identical to decisions that would have been made by the Bush administration-could be justified even under theories of executive power and the rule of law that differ substantially from those of President Obama's predecessor. What is missing is what Yale literature professor David Bromwich has called "the middle layer of explanation" in politics:104 "This is the level at which one must articulate the reasons for a policy, along with the understanding of the public good from which the policy has issued and the historical context that makes it necessary and desirable." 105 Individual Obama administration decisions may well be defensible along these lines, but that defense cannot be merely implicit. It must be

102. David Cole, What to Do About Guantánamo?, N.Y. Rev. of Books (Oct. 14, 2010), http://www.nybooks. com/articles/archives/2010/oct/14/what-do-about-guantanamo.

103. $I d$.

104. David Bromwich, The Dying Art of Political Explanation, Huffington Post (Oct. 16, 2010, 2:32 PM), http://www.huffingtonpost.com/david-bromwich/the-dying-art-of-politica_b_765361.html.

105. $I d$. 
THE PROSPECTS FOR A DEMOCRATIC PRESIDENCY IN A POST-9/11 WORLD

reiterated on many more occasions than a single speech five months into the presidency.

Why has the Obama administration not done this? There are, I imagine, at least three reasons. The first is a chronic institutional reluctance within the executive branch to suggest limits or to support constraints on its powers. This is not invariable-Presidents Ford and Carter both supported congressional regulation of presidential records in the wake of Watergate, ${ }^{106}$ and President James Carter supported both the Ethics in Government Act of $1978^{107}$ and the Foreign Intelligence Surveillance Act. But where Presidents perceive that they are likely be judged on accomplishment, there would be an understandable reluctance to risk limiting their own (or their successors') sphere of potential action. In the case of President Obamawho is facing enormous problems on both the domestic and international fronts, as well as a divided government-this risk may seem particularly unwelcome. And, especially in the national security sphere, I suspect that there are many career personnel in the executive branch who would actually embrace Bush-style presidentialism as a matter of principle and so would not counsel any form of presidential modesty about executive power.

The second is politics. With the country still grappling with the effects of a devastating recession, as well as the need for pressing action on healthcare, climate change, and immigration, the President might well want to avoid the appearance of diluting his focus. Moreover, since the Johnson administration, Republicans have consistently — and with some success - cowed the Democrats by portraying them as soft on national security issues. The partisan pushback against any Obama administration effort to reinvigorate the rule of law in the national security context is likely to be vicious, threatening to erode whatever modicum of goodwill might otherwise be available to accomplish seemingly more concrete and immediate objectives. This, of course, is not hypothetical. We can see it in Republican efforts to derail the closing of Guantánamo and in proposals to prohibit the trial of foreign terrorists in civilian courts ${ }^{108}$ - a practice that Republicans seemed happier to live with under George W. Bush. ${ }^{109}$

And the third is insularity. From inside the administration, the philosophical distance between it and its predecessor, even when similar decisions are made, may

106. Nixon v. Admin. of Gen. Servs., 433 U.S. 425, 441 (1977).

107. Pub. L. 95-521, 92 Stat. 1824 (1978).

108. E.g., Ike Skelton National Defense Authorization Act for Fiscal Year 2011, Pub. L. No. 111-383, 124 Stat. 4137, 4351 (2011) (prohibiting the use of appropriated funds to transfer Guantánamo detainees to the United States); Naftali Bendavid \& Jess Bravin, Republicans Step Up Protests of Civilian Terror Trials, Wall St. J., Feb. 1, 2010, at A5, available at http://online.wsj.com/article/SB100014240527487037625 04575037550051072986.html.

109. On the number of terrorism-related convictions in civilian court under President Bush, see Letter from Sen. Ronald Weich, Asst. Att'y Gen., to Sen. Leahy \& Sessions (Mar. 26, 2010), available at http:// www.justice.gov/cjs/docs/terrorism-crimes-letter.html ("319 convictions or guilty pleas in terrorism or terrorism-related cases arising from investigations conducted primarily after September 11, 2001 ... ." (quoting Dep't of Justice, FY2009 Budget and Performance Summary pt.1, at 1, http://www. justice.gov/jmd/2009summary/pdf/fy2009-bud-sum.pdf)). 
not look at all obscure. President Obama's May 2009 speech really did seem to signal a philosophical departure; as long as he sits in the Oval Office, the message still seems to be there-for administration insiders. The administration has also enjoyed, and in many cases continues to enjoy, the legal counsel of some of the most thoughtful progressive lawyers one could imagine-people like David Barron, ${ }^{110}$ Harold Koh, ${ }^{111}$ Neal Katyal, ${ }^{112}$ Martin Lederman, ${ }^{113}$ and even the President and Attorney General Holder themselves. With lawyers of such progressive credentials involved in the administration's decisionmaking - as compared to, say, David Addington, ${ }^{114}$ Jay Bybee, ${ }^{115}$ Alberto Gonzales, ${ }^{116}$ or John Yoo $^{117}$ - it may seem unthinkable to insiders

110. Harvard Law professor David Barron served in the Justice Department's OLC from 2009-2010, including a stint as acting assistant attorney general. Barron appointed Prinicpal Deputy Assistant Attorney General in DOJ's Office of Legal Counsel, Harv. L. ScH. (Jan. 20, 2009), http://www.law.harvard.edu/ news/2009/01/20_barron.html. With professor Martin Lederman, he wrote The Commander in Chief at the Lowest Ebb - Framing the Problem, Doctrine, and Original Understanding, a devastating critique of the Bush administration's position that the President, as Commander in Chief, acts outside Congress's permissible regulatory scope. David J. Barron \& Martin S. Lederman, The Commander in Chief at the Lowest Ebb-Framing the Problem, Doctrine, and Original Understanding, 121 Harv. L. Rev. 689 (2008).

111. Harold Koh, legal advisor to the Department of State, served in the Clinton administration as assistant secretary of state for Democracy, Human Rights and Labor. His biography on the website of Yale Law School, where he served as dean from 2005-2009, indicates he has won "more than thirty awards for his human rights work." Harold Hongju Koh, YALE L. ScH., http://www.law.yale.edu/faculty/HKoh.htm (last visited May 31, 2011).

112. Neal Katyal, acting solicitor general of the United States, was lead counsel for the petitioner in Hamdan v. Rumsfeld. 548 U.S. 557 (2006); See Neal K. Katyal, Geo. L., http://www.law.georgetown.edu/faculty/ facinfo/tab_faculty.cfm?Status=Faculty\&ID=272 (last visited May 31, 2011).

113. Georgetown law professor Martin Lederman was deputy assistant attorney general in the OLC from 2009-2010, and co-authored The Commander in Chief at the Lowest Ebb: Framing the Problem, Doctrine, and Original Understanding. Barron \& Lederman, supra note 110; Martin S. Lederman, Geo. L., http:// www.law.georgetown.edu/faculty/facinfo/tab_faculty.cfm?Status=Faculty\&ID=2134 (last visited May 31, 2011).

114. As counsel and then chief of staff to former vice president Dick Cheney, David Addington was "by far the most important member of the [Bush administration's] legal team when it came to orchestrating its presidential-power agenda." Charlie Savage, Takeover: The Return of the Imperial Presidency and the Subversion of American Democracy 83 (2007).

115. As assistant attorney general in charge of the OLC, Jay Bybee signed memoranda arguing the inapplicability of the Geneva Conventions to al-Qaeda and Taliban detainees, along with memoranda approving harsh interrogation techniques and the use of military commissions. The Torture Papers, supra note 9 , at $81,136,144,172$.

116. As White House counsel, Alberto Gonzales instructed his legal team "to be vigilant about seizing any opportunity to expand presidential power." SAVAGE, supra note 114, at 73 . He also presided over meetings that led to the purported legal justification of harsh interrogations for CIA detainees. Id. at 154-55. In March 2004, he participated in a notorious late-night visit to the hospitalized then attorney general John Ashcroft to elicit his reversal of then acting attorney general James Comey's refusal to approve the Terrorist Surveillance Program in its then current form. See Harold H. Bruff, Bad Advice: Bush's Lawyers in the War on Terror 153 (2009).

117. In the weeks immediately following September 11, the then deputy assistant attorney general in charge of the OLC, John Yoo, wrote a confidential analysis of the President's war powers that formed the 
that anyone could mistake their views of the presidency or the rule of law for the views of the Bush administration. Of course, except for the President, these names are all but unknown to the general public, and the fact of their availability for public service during the Obama administration is unlikely by itself to lay any kind of groundwork for a re-imagination of the presidency.

It is understandable, based on these reasons, why the Obama administration might seem especially hesitant, perhaps even afraid, to mount a full-throated campaign for a view of the presidency that differs from Bush-Cheney presidentialism. But it is a critical project to undertake. I have previously argued in some detail that the Bush-Cheney view of the presidency is harmful to governance. ${ }^{118}$ It makes the bureaucracy less accountable. ${ }^{119}$ It leads to bad, sometimes unlawful, decisionmaking. It creates an organizational ethos of entitlement that undermines conscientious government lawyering. What makes full-throated resistance to presidentialism so critical, moreover, is that we are living in a moment when contemporary American culture seemingly has no room for an account of the presidency that is not fundamentally hierarchical and unaccountable.

In discussing his own presidency, George W. Bush and his supporters were fond of connecting to two images-that of the corporate $\mathrm{CEO}^{120}$ and that of the Commander in Chief. ${ }^{121}$ With regard to the latter, it seemed to be all but forgotten that the constitutional job title is "Commander in Chief," not of the government, but "of the Army and Navy of the United States, and of the Militia of the Several States, when called into the actual Service of the United States." ${ }^{22}$ Indeed, perhaps the most obvious textual refutation of the argument that the Article II Vesting Clause ${ }^{123}$ demands a "unitary presidency" is that such a reading of the presidency would make the Commander-in-Chief Clause superfluous.

Free-market business values have become so hegemonic in our public discourse, however, that it is truly the conflation of the constitutional chief executive with the corporate CEO that is most dangerous. I have long been puzzled by conservative voters' seeming approbation of the imperial presidency because such a presidency is

analytic framework for much of OLC's lawyering regarding the War on Terror, and helped write even those memos on interrogation techniques and the Geneva Conventions that appeared over Jay Bybee's signature. See Savage, supra note 114, at 79; The Torture Papers, supra note 9, at 3, 38, 218. Even the Margolis Memo explaining the decision not to pursue disciplinary action against professor Yoo called that memo "decidedly one-sided and conclusory." Margolis Memo, supra note 90, at 45.

118. See generally Shane, supra note 3.

119. Id. at 158-67; Heidi Kitrosser, The Accountable Executive, 93 Minn. L. Rev. 1741, 1744 (2009).

120. See James Carney \& John F. Dickerson, Inside the Mind of the CEO President, Time (Jul. 28, 2002), http://www.time.com/time/printout/0,8816,331981,00.html.

121. See Interview by Brit Hume with the President and Former President Bush, D.C. (Fox News broadcast Jan. 11, 2009), 2009 WL 57564, at *1 ("I'm going to miss being the Commander-in-Chief of the military. Earlier the past week I had the honor of having a military parade that said goodbye to the Commander-in-Chief and it was an emotional moment for me and Laura.").

122. U.S. Const. art. II, § 2, cl. 1.

123. U.S. Const. art. II, $\S 1$, cl. 1. 
hardly associated with either smaller government or libertarian values. Yet, accepting the President as our national CEO seemingly drapes the President in the imagined virtues of the private sector. The metaphor also helps excuse the President's resistance to being accountable to anyone but his base; CEO's, after all, are ultimately beholden to their shareholders. When someone like former U.N. ambassador John Bolton says, "The President has a responsibility to be true to the people who voted for him .... Otherwise, what's the point of having elections?" ${ }^{24}$ he is utterly mistaking marketplace accountability for a President's fiduciary accountability to the nation as a whole.

Jack Goldsmith, in his memoir of public service during the Bush administration, bemoans that administration's presidentialist dogmatism, but states: "It is not right to say, as some have done, that [Vice President Cheney and his chief of staff, David Addington] took advantage of the 9/11 attacks to implement a radical pro-President agenda." ${ }^{125}$ With respect, I think history will point to a different conclusion. ${ }^{126}$ Indeed, the Bush-Cheney success in just that agenda, which exploited 9/11 shamelesslessly, may now well make it appear politically perilous to pursue a different conception with any vigor. Unless such an effort is made, however, no clear alternative narrative of the presidency is going to become available-either to those who wield executive power or to those who would hold our Presidents accountable.

\section{CONCLUSION}

In mid-February 2011, when popular protests erupted in Libya against the autocratic rule of Colonel Muammar Qadhafi, Qadhafi answered with violence, opening fire on unarmed crowds. ${ }^{127}$ There followed a series of retaliatory diplomatic responses, involving the United States, the United Nations, the African Union, and other nations and international bodies. ${ }^{128}$ When Qadhafi intensified his campaign of violent suppression, the U.N. Security Council adopted Resolution 1973, demanding an immediate ceasefire in Libya and authorizing member states to engage in the use of all necessary measures to protect Libyan civilians. ${ }^{129}$ Two days later, the United States commenced military operations to enforce Resolution 1973, launching strikes against Qadhafi's air defense systems and military airfields in order to lay the

124. Interview by Jon Stewart with John Bolton, The Daily Show (Comedy Central television broadcast Mar. 20, 2007), available at http://www.thedailyshow.com/watch/tue-march-20-2007/john-bolton.

125. Goldsmith, supra note 4 , at 89.

126. See generally SAVAGE, supra note 114 .

127. David D. Kirkpatrick \& Kareem Fahim, Qaddafi Forces Violently Quell Capital Protest, N.Y. Times, Feb. 26, 2011, at A1, available at http://www.nytimes.com/2011/02/26/world/africa/26libya.html.

128. See Memorandum Op. from Office of Legal Counsel, U.S. Dep't of Justice, to the Att'y Gen. (Apr. 1, 2011), 2011 WL 1459998, at *1-3 [hereinafter OLC Libya Opinion], http://www.justice.gov/olc/2011/ authority-military-use-in-libya.pdf.

129. S.C. Res. 1973, ๆ 4, U.N. Doc. S/RES/1973 (Mar. 17, 2011), http://daccess-dds-ny.un.org/doc/ UNDOC/GEN/N11/268/39/PDF/N1126839.pdf?OpenElement. 
groundwork for a no-fly zone over Libya. ${ }^{130}$ On March 21, 2011, President Obama formally reported these events to congressional leadership "consistent with the War Powers Resolution" (WPR). ${ }^{131}$ Although the President did not cite the section of the WPR to which he was referring, it was presumably section 4, which through the operation of subsection 4(a)(1) requires the President to report to Congress within forty-eight hours "in any case in which United States Armed Forces are introduced [without a prior declaration of war]-into hostilities or into situations where imminent involvement in hostilities is clearly indicated by the circumstances." $132 \mathrm{On}$ April 1, 2011, the Justice Department's OLC issued an opinion memorializing its advice that the President had acted within his constitutional authority to undertake such a military initiative without explicit congressional authorization. ${ }^{133}$ It based this conclusion on the weightiness of the U.S. national interests involved and the contextual facts indicating that the military's efforts would be "limited in their nature, scope, and duration." ${ }^{134}$ OLC explicitly cited the WPR as implicitly recognizing presidential authority of this scope. ${ }^{135}$

From the standpoint of separation of powers law and practice, these events seem wholly conventional. Section 5(b) of the WPR, however, requires the Presidentwithin sixty days of his report to Congress-to withdraw armed forces from any engagement in which he was required to report under section 4(a)(1). ${ }^{136}$ The sixtyday rule would be inapplicable only if Congress had-since the President's report-explicitly authorized the President's continuing action, or "if the President determines and certifies to the Congress in writing that unavoidable military necessity respecting the safety of United States Armed Forces requires the continued use of such armed forces in the course of bringing about a prompt removal of such forces." ${ }^{137}$ In the latter case, the WPR gives the President up to thirty additional days to withdraw. ${ }^{138}$ The administration's legal posture went from conventional to totally obscure when the sixty-day limit-which ran on May 20, 2011-came and went without any further report to Congress, any request for or grant of explicit authority, or any certification that the President needed an additional thirty days to effectuate a safe withdrawal. The only articulation of the administration's legal position came

130. Letter from the President to the Speaker of the House of Representatives \& the President Pro Tempore of the Senate (Mar. 21, 2011), available at http://www.whitehouse.gov/the-press-office/2011/03/21/ letter-president-regarding-commencement-operations-libya.

131. Id.

132. Pub. L. 93-148, 87 Stat. 555-56, § 4(a)(1) (codified at 50 U.S.C. § 1543(a)(1) (2006)).

133. OLC Libya Opinion, supra note 128 , at ${ }^{*} 1$.

134. Id. at *13-14.

135. $I d$. at $* 8$.

136. Pub. L. $93-148,87$ Stat. 556, § 5(b) (codified at 50 U.S.C. § 1544(b) (2006)).

137. $I d$.

138. Id. 
from White House Press Secretary Jay Carney, who said on May 20, "We believe the President has acted in a way that's consistent with the War Powers Resolution."139

Matters thus stood until, under congressional pressure, the White House released a report ${ }^{140}$ on June 15, 2011, with the heading, "United States Activities in Libya." ${ }^{41}$ That report-which bears no letterhead, no date, and no signature-offers a oneparagraph conclusory statement of the administration's position on applying the sixty-day rule to its Libya campaign:

Given the important U.S. interests served by U.S. military operations in Libya and the limited nature, scope and duration of the anticipated actions, the President had constitutional authority, as Commander in Chief and Chief Executive and pursuant to his foreign affairs powers, to direct such limited military operations abroad. The President is of the view that the current U.S. military operations in Libya are consistent with the War Powers Resolution and do not under that law require further congressional authorization, because U.S. military operations are distinct from the kind of "hostilities" contemplated by the Resolution's 60 day termination provision. U.S. forces are playing a constrained and supporting role in a multinational coalition, whose operations are both legitimated by and limited to the terms of a United Nations Security Council Resolution that authorizes the use of force solely to protect civilians and civilian populated areas under attack or threat of attack and to enforce a no-fly zone and an arms embargo. U.S. operations do not involve sustained fighting or active exchanges of fire with hostile forces, nor do they involve the presence of U.S. ground troops, U.S. casualties or a serious threat thereof, or any significant chance of escalation into a conflict characterized by those factors. ${ }^{142}$

In other words, the administration deems section 5 of the WPR inapplicable because-given a series of what seem to be seven or eight limiting factors (none singled out as weightier or more critical than the others) - the campaign that the United States launched on March 19, 2011, was transformed into something less than "hostilities" before the expiration of sixty days.

There is, as it happens, no authoritative source of interpretation that provides an irrefutable analysis confirming or rebuffing the administration's interpretation of "hostilities." It ought to be observed, however, that, compared to earlier instances in which Presidents urged what might be called the "sub-hostilities theory," the Libya

139. Press Briefing by Press Sec'y Jay Carney (May 20, 2011), available at http://www.whitehouse.gov/thepress-office/2011/05/20/press-briefing-press-secretary-jay-carney-5202011.

140. Charlie Savage \& Mark Landler, White House Defends Continuing U.S. Role in Libya Operation, N.Y. Times, June 16, 2011, at A16, available at http://www.nytimes.com/2011/06/16/us/politics/16powers. html (describing both the release of the report and congressional pressure on the White House).

141. White House Admin., United States Activities in Libya (2011) [hereinafter White House Libya RePORT], http://s3.documentcloud.org/documents/204680/united-states-activities-in-libya6-15-11.pdf.

142. Id. at 25 . 
campaign is offensive, sustained, and continuous. ${ }^{143}$ Moreover, U.S. military personnel continued flying sorties over Libya even after the transfer of command responsibility to NATO. ${ }^{144}$ There is an obviously steep uphill climb for any legal argument that U.S. military involvement in the ongoing use of lethal force against an adversary who did not attack the United States falls short of what the WPR calls "hostilities."

What is just as confounding as the administration's legal argument, however, is its overall management of the legal issues. Although getting congressional support for a joint resolution in support of Resolution 1973 might have proved challenging, it probably could have been accomplished had the President sought such a resolution at the time of his initial report to Congress. If the administration wanted to argue that the April 4 transition of military operations to NATO ended U.S. involvement in "hostilities" - as the word is used in the WPR-it should have said so on April 4. It should certainly have said so prior to the May 20 expiration of the sixty days that passed after the President's initial report to Congress. Instead, without even the cover of congressional appropriations to ratify the Libyan engagement, the President found himself, as of mid-June 2011, still resting his Libyan initiative entirely on inherent constitutional power to unilaterally undertake military operations "limited in nature, scope, and duration." This seems fairly problematic given that the NATO mandate, as of this writing, has already been extended to September 30, 2011, ${ }^{145}$ at which point the project will have lasted more than six months. Libya 2011, for war powers purposes, is not Grenada $1983 .{ }^{146}$

As America's global military strategy begins to rely ever more heavily on unmanned drones, off-shore missiles, and perhaps other remotely deployed weapons systems, there is reason to fear that the Libya episode could live on as a precedent very substantially undermining executive accountability to Congress for military action. As this essay goes to press, it appears as if the administration has simply squandered an obvious opportunity to combine a humanitarian mission abroad with a compelling new narrative on the role of the presidency-a narrative based on rule of law, checks and balances, and genuine public accountability. This would have only required going to Congress. The narrative I am imagining might variously be called, "the Checks and Balances Presidency," "the Constitutionalist Presidency," "the Accountable Presidency," "the Rule of Law Presidency," or perhaps simply, "the Democratic Presidency." I like "democratic" the best because it captures the ideals of

143. Jack Goldsmith, Problems with the Obama Administration's War Powers Resolution Theory, Lawfare (June 16, 2011, 8:38 AM), http://www.lawfareblog.com/2011/06/problems-with-the-obama-administration'swar-powers-resolution-theory-2/.

144. Charlie Savage \& Thom Shanker, Scores of U.S. Strikes in Libya Followed Handoff to NATO, N.Y. Times, June 21, 2011, at A8, available at http://www.nytimes.com/2011/06/21/world/africa/21powers.html? $\mathrm{r}=1 \&$ scp $=4 \&$ sq=libya\&st=cse.

145. See White House Libya Report, supra note 141, at 11.

146. Bernard Gwertzman, Grenada Fighting is Ended, U.S. Says; Mop-Up Continues, N.Y. Times, Nov. 3, 1983, at A1, available at http://www.nytimes.com/1983/11/03/world/grenada-fighting-is-ended-ussays-mop-up-continues.html (reporting Defense Department statement that hostilities had ceased as of November 2, 1983, following the U.S. invasion of Grenada on October 25, 1983). 
presidential accountability to law as embodied in our Constitution or as enacted by Congress through our democratic legislative process and of day-to-day presidential accountability to attend to the interests of all of the American people, not just an electoral base.

In elaborating on that ideal, President Obama would do well to go back to his own words of May 2009 and give them clearer-and repeated-specification:

We uphold our most cherished values not only because doing so is right, but because it strengthens our country and it keeps us safe. Time and again, our values have been our best national security asset-in war and peace; in times of ease and in eras of upheaval....

[Regarding Guantánamo,] [t]he courts have spoken . . . . I cannot ignore these rulings because as President, I too am bound by the law. The United States is a nation of laws and so we must abide by these rulings....

I ran for President promising transparency, and I meant what I said. And that's why, whenever possible, my administration will make all information available to the American people so that they can make informed judgments and hold us accountable .... Whenever we cannot release certain information to the public for valid national security reasons, I will insist that there is oversight of my actions by Congress or by the courts ....

We seek the strongest and most sustainable legal framework for addressing [national security] issues in the long term-not to serve immediate politics, but to do what's right over the long term. By doing that we can leave behind a legacy that outlasts my administration, my presidency, that endures for the next President and the President after that - a legacy that protects the American people and enjoys a broad legitimacy at home and abroad. ${ }^{147}$

There is nothing impractical about this view of the presidency, but for such a view to endure as a potent counter-narrative to Bush-Cheney presidentialism, the Obama administration must consistently test its actions according to these standards-and either defend its actions within a Democratic Presidency framework or revise those actions in deference to the rule of law and the system of accountability on which our nation depends. That project would truly do honor to the memory of September 11.

147. Obama Nat'1 Sec. Remarks, supra note 7. 